o. Benedykt J. Huculak OFM

Wyższe Seminarium Duchowne w Kalwarii Zebrzydowskiej

DOI: $10.15290 /$ std.2015.01.06

\title{
ZARYS ANTROPOLOGII KOŚCIOŁA GRECKIEGO
}

\section{THE OUTLINE OF THE GREEK CHURCH ANTHROPOLOGY}

The lecture deals with the peculiarity of the anthropology of Eastern Christians, which in broad outline is already present in the writings of many Greek Fathers. It consists especially in considering state of divine grace as divinisation (théôsis) of man. Its other distinctive features are real difference between image and likeness of God and threefold composition of man, according to Platonic expression of saint Paul: "your spirit and soul and body" (1 Thess 5, 23). Because Greek anthropology basicly agrees with Latine doctrine and in the new orthodox theology it obtains more and more attention, it seems that exchange of ideas in this field between Western and Eastern theologians is advisable, also in order to facilitate their dialogue on the main subjects.

Key words: divinisation (deification), spirit-soul-body, image of God, likeness of God, original sin.

Antropologia, obok nauki o Trójcy oraz o Wcieleniu, należy do głównych działów teologii, bo - zwłaszcza na Wschodzie - jest to rzecz o łasce Boga w Trójcy Jedynego, udzielanej na podstawie zasług Syna Wcielonego. Jeśli w nauce o Trójcy należy pilnie odróżniać wykład Ojców greckich od tego, co w wieku IX wymyślił Focjusz ${ }^{1}$, to w antropologii tak wielka czujność raczej nie jest konieczna, bo również teologowie zwani prawosławnymi zgłębiają główny nurt nauczania Ojców, nawet je porządkując oraz rozwijając, jak Grecy P. Bratsiotis

J. Slipyj, Die Trinitätslehre des byzantinischen Patriarchen Photios, w: Opera omnia I, Rzym 1968, s. 91-158; B. J. Huculak, W sprawie odniesienia pogladu Focjusza do Symbolu Nicejsko-Konstantynopolitańskiego, „Analecta Cracoviensia” 25 (1993), s. 147-154. 
i N. Nissiotis czy Rosjanie, począwszy od przyjaciela katolików Wł. Sołowjowa przy końcu wieku XIX, w nurcie tzw. sofiologii, gdzie pojęciem kluczowym jest Bogoczłowieczeństwo, pojmowane w zarysie dogmatu chalcedońskiego².

Można więc przyjąć, że nauczanie wschodnie o człowieku nie różni się zasadniczo od łacińskiego - zwłaszcza na poziomie dogmatu - lecz wykazuje tylko własny odcień, teologiczne znamię: tak jak przy pełnej zgodzie dogmatycznej, w wielu sprawach różni się wykład katolickich Szkół, a w danej sprawie najlepszym obrazem jest ów sławny spór de auxiliis gratiae z końca wieku XVI, kiedy to stronom papież nakazał milczenie.

Wspomniane zaś pilne odróżnianie, zwłaszcza w nauce o Duchu Świętym i Biskupie Rzymskim jest konieczne nie tylko ze względu na to, że focjanie od wieku IX - mimo ważnych sakramentów - są w takiej mierze chrześcijanami prawosławnymi (orthódoxoi), czyli prawowiernymi, w jakiej luteranie są ewangelikami, czyli uczniami rzekomo wiernymi Ewangelii, lecz także dlatego, że ostatnio jakaś mgła zdaje się spowijać nawet wysokie piętra nauczania w Kościele, jeśli np. w Katechizmie teologię prawosławną utożsamia się z tradycją wschodnią.

Według tej jednak tradycji - w paśmie północnobizantyńskim - Duch pochodzi od Ojca diá tou Hyioú (przez Syna) - czyli przy Jego udziale - natomiast focjanie twierdzą, jakoby Duch pochodził ek mónou tou Patrós (jedynie od Ojca) ${ }^{3}$. Poza tym zaznacza się pojmowanie papieża jako pierwszego pośród patriarchów i biskupów równych, przy pośrednim (implicite) odsuwaniu dogmatu o jego pierwszeństwie także zwierzchnim, co jednak wyraził już Klemens I, rówieśnik Jana Apostoła, gdy w roku 96 napisał wprawdzie ojcowski, ale zwierzchni list do burzliwych Koryntian, którzy usunęli swoich duszpasterzy, a pod koniec wieku II papież Wiktor nawet klątwą zagroził biskupom metropolii Efezu, gdyby nie przyjęli ogólnokościelnej daty obchodzenia święta Wielkanocy.

Antropologia wschodnia zawiera nauczanie o łasce, którego pojęciem kluczowym jest théôsis - przebóstwienie człowieka. Ono jest nie tylko tłem, lecz także składnikiem wszystkich działów tej nauki. Obok dwóch głównych, jakimi są stworzenie człowieka na obraz i podobieństwo Boże oraz grzech pierworodny, dochodzi obraz człowieka - zwłaszcza chrześcijanina - jako bytu

$2 \quad$ T. Špidlik, Myśl rosyjska. Inna wizja człowieka, tłum. J. Dembska, Warszawa 2000; J. Tyciak, Die Liturgie als Quelle östlicher Frömmigkeit, Fryburg Br. 1937, s. 108-125; J. Klinger, Kilka problemów zwiazanych z nauka o Trójcy Świętej w prawosławnej teologii XX wieku, w: idem, O istocie prawosławia. Wybór pism (wyd. M. Klinger, H. Paprocki), Warszawa 1983, s. 193-195.

3 Katechizm Kościoła Katolickiego, 247-248; Jan Paweł II, Katecheza Duch, który od Ojcai Syna pochodzi (7 XI 1990), w: idem, Wierze w Ducha Świętego, Pana i Ożywiciela, Warszawa 1992, s. 274-275; B. J. Huculak, Najświętsza Trójca na tle dzieła zbawczego, Kalwaria Zebrzydowska 2000, s. 33-66. 
trójskładnikowego, który jest nie tylko swoistym mikrokosmosem, lecz także królewsko-kapłańskim pośrednikiem (1 P 2,9) między stworzeniem a Bogiem, uczestnicząc w jedynym pośrednictwie Pana Jezusa Chrystusa.

\section{Trzy warstwy: duch, dusza i ciało}

Jak objawienie imienia Boga w postaci Jahveh (Jestem) - czyli w grecko-apostolskiej Septuagincie ho Ôn (Istniejący) - dane Mojżeszowi (Wj 3, 14)4, zostało w Testamencie Nowym uściślone twierdzeniem, że „Bóg agápê estín - jest miłością” (J 4, 16) - tak wypowiedź pierwszej księgi Biblii, że „Pan Bóg ulepił człowieka z prochu ziemi i tchnął w jego twarz pnoến zôếs - dech życia" $(\operatorname{Rdz} 2,7)$, została jakby uściślona przez Pawła, który kończąc swój pierwszy list, tak zachęcał wiernych w Tesalonice: „Sam Bóg pokoju niech uświęci was całych, a nienaruszony duch wasz i dusza, i ciało niech będą nienagannie zachowane na przyjście Pana naszego Jezusa Chrystusa" (1 Tes 5, 23). Oto w części duchowej starożytnego zarysu dwudzielnego Paweł wyróżnia dwie warstwy, skąd pojawia się wnikliwy obraz trójdzielny: pnéuma kai psychế kai sốma - duch i dusza, i ciało.

Po pierwsze, idąc od dołu, jest 'ciało', ów biblijny „proch ziemi”, czyli składnik materialny. Warto zauważyć, że na oznaczenie ciała język grecki ma dwa słowa, które wskazują na jego odróżnione strony. Otóż wyraz sarx oznacza je pod względem kruchości, podległości bólowi i zniszczeniu. Użył go np. Jan, gdy na początku Ewangelii napisał, że "Słowo stało się ciałem (sarx egéneto)" (J 1, 14). Drugim jest wyraz sốma, wskazujący na stronę dodatnią ciała jako składnika natury ludzkiej, w której godności ono uczestniczy. Oto np. u Łukasza czytamy, że gdy niewiasty w dniu Zmartwychwstania o świcie weszły do grobu, ouch héuron to sốma tou Kyríou Iêsoú - nie znalazły ciała Pana Jezusa $(24,3)$. Wcześniej zaś, podczas Wieczerzy, wziął On chleb i przeistaczając go, dał uczniom mówiąc: "Weźcie, toútó estin to sốmá mou - to jest ciało moje” (Mk 14, 72). Tego właśnie słowa użył Paweł, wskazując na trójdzielność ludzką.

Po drugie, jest 'dusza ( $p s y c h e ̂$ '), czyli składnik, który ożywia i porusza ciało; a ma ona trzy warstwy: roślinną, gdzie jest tylko życie; zwierzęcą, gdzie ponadto jest odczuwanie i ruch; i ściśle ludzką, czyli samoświadomą, wyposażoną w rozum, wolę i uczucia. Jest to dusza rozumująca, zdolna do tworzenia pojęć ogólnych poprzez ich wyodrębnianie, jakby wyciąganie (abstractio) z wielu jednorodnych przypadków jednostkowych, a także - przechodzenie od przesłanek do wniosków i twierdzeń. Składnikiem trzecim i najwznioślejszym według Pawła jest 'duch (pnéuma)'. Oczywiście nie jest to Duch Święty, choć między obydwoma zachodzi więź ścisła, gdyż to właśnie poprzez swego ducha człowiek

$4 \quad$ Tłumaczono je także w postaci Egố eimí (Ja-jestem): J 8, 24. 28. 58; 13, 19; 18, 5. 6. 
wstępuje w więź z Bogiem i otwiera się na Jego dary nadprzyrodzone, w czym osobliwie czynny jest właśnie Duch Święty 5 .

Swoją duszą więc podejmuje człowiek badania naukowe i filozoficzne, porządkując i rozwijając dane doświadczenia zmysłów drogą rozumowania wnioskującego. Swoim duchem zaś przyjmuje on wieczną prawdę o Bogu lub o dogłębnej istocie bytów stworzonych, co jednak dzieje się już nie po linii kolejnych kroków wnioskowania, lecz całościowego wejrzenia, czyli wglądu (łac. intuitio), co Grecy nazywali słowem theôría od wyrazu théama - ogląd, także w teatrze (théatron). Izaak Syryjczyk nazywa je 'poznaniem prostym', a Latyni - do których należymy - zwą to contemplatio - gotowym oglądem całościowym.

Niektórzy Ojcowie greccy posługują się wprawdzie zarysem dwudzielnym, opisując człowieka jako jedność duszy i ciała, lecz w tym przypadku ów 'duch' Pawłowy jest tam obecny jako podrozdział zwany szczytem duszy (łac. apex mentis). Potrójny jednak obraz - ciało, dusza i duch - na Wschodzie uważa się za dokładniejszy, zwłaszcza w czasach nowożytnych, kiedy to kultura i kształcenie młodzieży skupia się niemal wyłącznie na ćwiczeniu rozumu, i to pod kątem obfitszej wytwórczości, zwłaszcza przemysłowej; a wola wchodzi znacznie mniej w rachubę, podczas gdy wręcz odłogiem leży poczucie wartości, piękna oraz dobra ${ }^{6}$. W większości przypadków człowiek nie jest świadom posiadania składnika najgłębszego i najwznioślejszego, jakim jest jego pnéuma - duch. Inaczej było w pierwszych wiekach i w średniowieczu, u którego początków np. Jan z Damaszku, ostatni z Ojców greckich, napisał o Maryi Pannie: „Ona jedna zachowała nieskalane dziewictwo duszy, ducha i ciała"”.

Duch przeto w człowieku jest jakby anteną, która może odbierać fale nadprzyrodzone, a jednocześnie naczyniem, gdzie składane są dary Ducha Świętego, przede wszystkim zaś łaska uświęcająca, powiększana lub przywracana poprzez sakramenty (mystếria) ${ }^{8}$. - Istnieje pewna klamra, łącząca początek Biblii z jej końcem, a jest to obraz tchnienia Boga eís to prósôpon - na twarz człowieka ( $\mathrm{Rdz} 2,7)$. W Księdze Rodzaju jest to tchnienie stwórcze, które człowieka - poprzez wyposażenie go w „ducha” - uczyniło zdolnym do przyjęcia Ducha Świętego i do wspólnoty z Bogiem, a w Ewangelii Jana jest to udzielenie tegoż Ducha uczniom, bo oto zmartwychwstały Jezus „tchnął na nich i rzekł im: Lábete Pnéuma hágion - Weźmijcie Ducha Świętego. Którym odpuścicie

5 Orygenes, Komentarz do Ewangelii Jana II, rozdz. 10, n. 75: Sources Chrétiennes 120, s. 257; Bazyli, O Duchu Świętym, rozdz. 25: ibidem 17, s. 222 (PG 32, 177b).

T. Špidlik SI, Myśl rosyjska. Inna wizja człowieka, s. 15-16.

Mowa VI na Narodzenie Najświętszej Maryi Panny, n. 4-6.

$8 \quad$ N. Bux, M. Loconsole, I Misteri degli orientali. I sacramenti bizantini comparati con la liturgia romana e i riti giudaici, Siena 2006; Y. Spiteris, Ostatni Ojcowie Kościoła: Kabasilas $i$ Palamas, tłum. B. Widła, Warszawa 2006, s. 53-67. 
grzechy, są im odpuszczone, a którym zatrzymacie, są im zatrzymane” (J 20, 22-23).

Trójdzielność bytu ludzkiego w Nowym Testamencie i w teologii greckiej jest najczęściej ukazywana w obrazie człowieka ubogaconego darem sakramentów, począwszy od chrztu, kiedy to - oblekłszy Chrystusa (Ga 3, 27) - stał się on kainế ktísis - nowym stworzeniem (2 Kor 5, 17; Ga 5, 15). „To, co dawne - rzecze Paweł - minęło, a oto [wszystko] stało się nowe" (2 Kor 5, 17), bo w duchu człowieka zamieszkał Duch Święty ze swymi darami nadprzyrodzonymi. Wierni chrześcijanie więc jakby „narodzili się ponownie” (J 3, 3. 7) - jak Pan rzekł Nikodemowi - bo ich składnikiem trzecim obok duszy i ciała jest duch, owo naczynie teraz napełnione łaską, dzięki której - jak mówi Piotr - oni stali się theías koinônoí phýseôs - uczestnikami natury Boskiej (2 P 1, 4).

\section{Stworzenie na „obraz i podobieństwo” Boga}

Pierwszy teolog systematyczny, Tertulianowi współczesny Ireneusz, nazywany Liońskim od miejsca posługi, a rodem Grek ze Smyrny w pobliżu Efezu, uczeń Polikarpa i duchowy wnuk Jana Apostoła9 , napisał, że „chwałą Boga jest człowiek żyjący, a chwałą człowieka jest oglądanie Boga" ${ }^{10}$. Rzeczywiście, rodzaj ludzki jest uwieńczeniem dzieła stworzenia, na co wskazuje również to, że w szóstym, ostatnim dniu tegoż dzieła, do siebie

Bóg rzekł: „Uczyńmy człowieka na obraz nasz i na podobieństwo (kat'eikóna hêmetéran kai kath'homoîosin). Niech [ludzie] zapanują nad rybami w morzu, nad ptakami na niebie, nad bydlem na ziemi i nad wszystkimi zwierzętami pełzającymi po ziemi”. Stworzył więc Bóg człowieka: kat'eikóna Theoú - na obraz Boga stworzył go; stworzył ich [ludzi] jako mężczyznę i niewiastę" (Rdz 1, 26-27).

Człowiek jest królem i kapłanem niższych warstw stworzenia ${ }^{11}$ tylko w owym jedynym „władcy królów ziemi” (Ap 1,5) i „wielkim arcykapłanie” (Hbr 4, 14), którym jest ,jedyny pośrednik między Bogiem a ludźmi, ánthrôpos Christós Iêsoús - człowiek Chrystus Jezus" (1 Tm 2, 5). Według ważnego nurtu teologii greckiej, który ciągnie się od Ireneusza w wieku II do przyjaciela wiernych

$9 \quad$ Benedykt XVI, Katecheza Sant'Ireneo di Lione (28 III 2007): „La sua opera va ben oltre la confutazione dell'eresia: si può dire infatti che egli si presenta come il primo grande teologo della Chiesa, che ha creato la teologia sistematica; egli stesso parla del sistema della teologia, cioè dell'interna coerenza di tutta la fede. Al centro della sua dottrina sta la questione della «Regola della fede» e della sua trasmissione. Per Ireneo la «Regola della fede» coincide in pratica con il Credo degli Apostoli, e ci dà la chiave per interpretare il Vangelo. Il Simbolo apostolico, che è una sorta di sintesi del Vangelo, ci aiuta a capire che cosa vuol dire, come dobbiamo leggere il Vangelo stesso".

10 Adversus haereses IV, c. 20 (w. 7).

11 L. Uspienski, Teologia ikony, Poznań 1993, s. 125. 
łacińskich, czyli naszych ojców, Maksyma Wyznawcy w wieku VII i do Izaaka Syryjczyka w VIII, powodem Wcielenia nie była potrzeba odkupienia człowieka z niewoli grzechu, ani nawet sama philanthrôpía tou Theoú - miłość Boga do człowieka, opiewana we wschodniej liturgii, bo Syn Boży przyjąłby naturę ludzką, nawet gdyby do upadku człowieka nie doszło ${ }^{12}$. W wieku XIV takie było stanowisko np. wybitnego teologa Mikołaja Kabasilasa rodem z Tesaloniki, którego prawosławni czczą jako świętego ${ }^{13}$.

Niezależnie od owych wczesnych i na Zachodzie raczej nieznanych źródeł greckich, to samo twierdzenie w wieku XIII przedłożył i obronił bł. Jan Duns Szkot, a głównie na jego wykładzie opiera się katolickie nauczanie o Chrystusie Królu i treść odnośnego święta, która - według starochrześcijańskiego prawidła Lex orandi [est] lex credendi (Prawo modlitwy jest prawem wiary) - graniczy $z$ dogmatem. Według tej nauki greckiej i łacińsko-franciszkańskiej, wspomniana philanthrôpía Boga należy już do porządku czasu i przestrzeni, bo w uprzednim, ponadczasowym swym wnętrzu troistym Bóg zamierzył Wcielenie Syna - w kolejności logiczno-warunkowej - zanim przewidział On stworzenie ludzi. To oni są stworzeni na obraz natury ludzkiej przewidzianej dla Syna Bożego. Ów porządek zamysłów nazywany jest też „naturalnym”, bo wynika on ze stanu rzeczy rozważanej pod kątem logicznym lub metafizycznym.

Ponieważ miłość jest samą istotą Boga, to jest oczywiste, że On - który agápê estín $(1 \mathrm{~J} 4,16)$ - miłuje w sposób uporządkowany i w stopniu najwyższym, a stąd wynika, że najpierw musi On kochać siebie, gdyż On jest dobrem najwyższym. Jest to biblijno-liturgiczny teocentryzm, naznaczony miłością Boga do samego siebie, która wynika z samej Jego istoty, a pojęciowo wyprzedza Jego miłość jako dar - głównie do ludzi - która ma odniesienie do czasu i przestrzeni ${ }^{14}$. Bóg więc miłuje siebie w swym bycie wewnętrznym - zarówno jednym co do istoty, jak i troistym według Osób - ale w kolejnej chwili pragnie On być miłowany przez kogoś, kto znajdowałby się jakoś na zewnątrz Niego. To zaś dokona się głównie we Wcieleniu Syna, a także w dziele stworzenia, zwłaszcza istot rozumnych, czyli aniołów i ludzi ${ }^{15}$. Święty Paweł mówi, że w zamyśle Bożym Pan Jezus był „pierworodnym między wielu braćmi (prôtótokos en polloís adelphoís)”

12 K. Ware, Kościót prawosławny, tłum. Wł. Misijuk, Białystok 2002, s. 249-250; Prawostawna droga, tlum. s. Nikolaia z Bussy-en-Othe, Białystok 1999, s. 75-76; P. Evdokimov, Prawostawie, tłum. J. Klinger, Warszawa 1964, s. 68-71.

Y. Spiteris, Ostatni Ojcowie Kościoła: Kabasilas i Palamas, s. 32-38.

14 L. Veuthey, Jan Duns Szkot - myśl teologiczna, tłum. M. Kaczyński, Niepokalanów 1988, s. 138-139.

15 Jan Duns Szkot, Reportata Parisiensia III, d. 7, q. 4: Opera omnia (wyd. Braci Mniejszych Obserwantów we Francji), t. XXIII, Paryż 1894, s. 303b: „W pierwszej chwili Bóg miłuje samego siebie, w drugiej miłuje siebie poprzez innych..., w trzeciej chce być miłowany 
$(\mathrm{Rz} 8,29)$ - którzy pod Jego przewodem i przez Niego mieli wielbić i miłować Boga - a także miał być On prôtótokos pásês ktíseôs - pierworodnym całego stworzenia (Kol 1, 15), które miało być Jego środowiskiem, uwarstwionym według doskonałości bytów ${ }^{16}$.

Ważne miejsce w teologii greckiej zajmuje pogląd, że Boży zamiar stworzenia człowieka „na obraz i podobieństwo” swoje ziścił się doskonale w odwiecznie przewidzianym człowieczeństwie Chrystusa, a poszczególni ludzie, począwszy od Adama są stwarzani na obraz Jezusa, który - jak rzecze Paweł - ,jest eikốn - obrazem Boga” (2 Kor 4, 4; Kol 1, 15). W innym zaś miejscu pisze: „Tych [ludzi], których uprzednio poznał, tych też przeznaczył na to, by się stali na wzór obrazu Jego Syna, aby On był pierworodnym pośród wielu braci" (Rz 8, 29): „na wzór obrazu Jego Syna [Wcielonego]”, a ściślej: symmórphous tês eikónos tou Hyioú autoú - [aby byli] współkształtni z obrazem, którym był i jest Jego Syn Wcielony.

O przyszłym Pomazańcu Boga, czyli Mesjaszu, prorok Izajasz rzekł, iż „na Nim spocznie Duch Boga" (11, 2). Nie dziwi więc wyznanie Jana Chrzciciela, który faryzeuszom tak rzekł:

Ujrzałem Ducha, który zstępował z nieba jak gołębica i émeinen - został na Nim [Jezusie]. Ja Go przedtem nie znałem, lecz Ten, kto mię posłał, abym chrzcił wodą, powiedział do mnie: „Ten, nad którym ujrzysz Ducha zstępującego i zostającego na Nim, jest Tym, który chrzci Duchem Świętym”. Ja to ujrzałem i zaświadczam, że On jest Synem Bożym (J 1, 32-34).

Sam Jezus wkrótce po swoim chrzcie w Jordanie odniósł do siebie prorocze słowa Izajasza: „Duch Pana [został] na Mnie, bo Mię namaścił” (Łk 4, 18; Iz 61, 1), a ściślej échrisén me - pomazał mię owym Boskim olejkiem (chrísma), którym jest Duch Święty, skąd słowu Pomazaniec (i hebrajskiemu Mesjasz) odpowiada grecki wyraz Christós. Jemu - jak sam wyznał Nikodemowi - Bóg „daje Ducha bez miary” (J 3, 34), natomiast ludziom „została dana łaska katá to metrón - według miary daru Chrystusa” (Ef 4, 7), bo „z Jego pełni wszyscy otrzymaliśmy - łaskę za łaską" (J 1, 16). Jak zaś Jezus jest przeobficie napełniony Duchem Świętym, tak też jest najwierniejszym obrazem Boga ${ }^{17}$, czyli Jego praobrazem, na którego wzór - jak pisze Paweł - został uczyniony człowiek (Rz 8, 29). „Jesteśmy bowiem Jego [Boga] dziełem, ktisthéntes en Christố Iêsoú

przez tego spośród innych, kto może Go miłować w stopniu najwyższym [...], we czwartej przewiduje tej natury... zjednoczenie [z boską Osobą Syna]".

16 M. Miguéns OFM, Base escriturística de la doctrina de Escoto sobre el primado de Cristo, w: De doctrina Ioannis Duns Scoti. Acta Congressus Scotistici Internationalis Oxonii et Edinburgi 11-17 IX 1966 celebrati (wyd. Komisja Szkotystyczna OFM) III: Problemata theologica, Rzym 1968, s. 138-168. 
- stworzeni w Chrystusie Jezusie dla dobrych czynów, które Bóg uprzednio przygotował, abyśmy je spełnili" $(\mathrm{Ef} 2,8)$.

Niniejszy pogląd bliższy był szkole antiochijskiej niż aleksandryjskiej, którapocząwszy od Klemensa i Orygenesa - pod wpływem filozofii greckiej, zwłaszcza platońskiej, upatrywała obraz Boży tylko w duszy człowieka, zwłaszcza w jego umyśle (noús) jako podmiocie łaski, ze względu na pewne jego pokrewieństwo z naturą Boską (syggéneia). Duży wpływ wywarła tu nauka o Wcieleniu Syna, nazywana odgórną, bo uwagę skupiała na Drugiej Osobie Trójcy, która zstąpiła w czas i przestrzeń, do własnej natury Boskiej dołączając ludzką, głównie jako czynnik narzędny, skąd określono ją dwumianem: Lógos - sarx. Za sprawą Ambrożego, dobrze znającego język grecki, nauczanie to pojawiło się na łacińskim Zachodzie, gdzie w pokoleniu następnym przyjął je Augustyn, a jego przemożny wpływ na teologię uczynił je niemal powszechnym.

W szkole natomiast antiochijsko-syryjskiej tradycje semickie i bliskość ojczyzny Jezusa wpłynęły na to, że godność obrazu Bożego przyznawano człowiekowi całemu. W przeciwieństwie do Aleksandrii podkreślano nieuszczuplone i samodzielne człowieczeństwo Chrystusa po linii teologii zwanej oddolną o dwumianie Lógos - ánthrôpos: jakże znamienne, że właśnie ánthrôpos, a nie tylko sarx, czyli nawet nie sốma. Uwagę skupiano na odwiecznym zamyśle Bożym, według którego człowiek Jezus w samej chwili swego poczęcia w łonie Dziewicy miał zostać objęty osobą Syna Bożego. Dlatego to Jezus w tym nurcie nauki Ojców nazywany jest Homo assumptus ${ }^{18}$.

Nauczanie Antiochii promieniowało na całą Azję Mniejszą, od wieku zaś IV - także poza cieśninę Bosfor, a głównie na Konstantynopol. Już jednak w wieku II pogląd ten wyznawał św. Ireneusz i starsza szkoła łacińska z genialnym Tertulianem, który znając cały dorobek wschodni dzięki doskonałej znajomości języka greckiego, napisał pierwszy w dziejach traktat antropologiczny pt. De anima (O duszy). Nurt antiochijski przeważa w nowożytnej teologii wschodniej, według której obrazem Bożym jest cały człowiek jako osobowy byt zdolny do ukazywania Boga, w miarę jak jego natura złożona pozwala się przenikać łaską przebóstwienia, więc osiągać podobieństwo Boże ${ }^{19}$. Jakże znamienne jest, że w czasach Cyryla i Metodego dla greckiego słowa hósios (świątobliwy) na ziemiach słowiańskich utworzono wyraz priepodóbnyj, czyli „bardzo podobny” do Boga, a przede wszystkim - do praobrazu, którym jest Jezus.

18 W wieku XIII, złotym wieku teologii, ów bezcenny wykład Ojców odżył pod piórem Jana Dunsa Szkota, który w wykładzie III księgi Piotra Lombarda swą genialną myśl rozwija, ująwszy zagadnienie na wskroś po antiocheńsku: Utrum Christus [Iesus] praedestinatus sit [ut fieret] Filius Dei; L. Seiller OFM, Un théologien scotiste - le Révérend Père Déodat de Basly (1862-1937), „La France Franciscaine” 21 (1938), s. 168-179. 
Michał Choniates, który tworzył na przełomie XII i XII wieku, napisał: „Gdy mówi się o tym, że Bóg stworzył człowieka na swój obraz, to słowo 'człowiek' nie oznacza ani samej tylko duszy, ani samego tylko ciała, lecz jedno i drugie razem"20. Jak dowodził metropolita Tesaloniki Grzegorz Palamas w I połowie XIV wieku, to, że ludzie mają ciało, nie czyni ich mniejszymi od aniołów, lecz nawet ich ponad nich wywyższa. Aniołowie wprawdzie są „czystymi” duchami, a natura ludzka - będąc zarówno materialną, jak i duchową - jest złożona, lecz to oznacza, że w porównaniu z anielską jest ona pełniejsza i obdarzona możliwościami większymi jako zwieńczenie całego stworzenia i jego streszczenie, nazwane mikrokosmosem, czyli 'małym wszechświatem'21.

\section{Rozróżnienie między obrazem a podobieństwem}

Podejmując nauczanie większości Ojców greckich - począwszy od Ireneusza - teologowie wschodni wskazują na różnicę między „obrazem” a „podobieństwem”. Otóż „obraz” oznacza wyposażenie możnościowe, uzdalniające do osiągnięcia życiowej wspólnoty z Bogiem, natomiast „podobieństwo” jest urzeczywistnieniem tej możności drogą starań i walki duchowej, więc osiągnięciem owej zadanej już w „obrazie” zażyłości z Bogiem² ${ }^{22}$. Według Maksyma dał Bóg człowiekowi udział we czterech swych właściwościach, którymi są: byt, wieczność, dobroć i mądrość23. Dwie pierwsze należą do istoty człowieka, przeto składają się na „obraz”, podczas gdy trzecia i czwarta są przedłożone i zadane jego staraniom o osiągnięcie celu, którym jest „podobieństwo”24.

Jan z Damaszku stwierdza: „Zwrot «na obraz» oznacza zdolność myślenia i stanowienia o sobie, a «na podobieństwo» - upodabnianie się [do Boga] w miarę sił przez cnotę"25. Obraz Boży oznacza wszystko to, co odróżnia nas od świata zwierząt i czyni podmiotem rozumnym i wolnym. Ten obraz ma jednak znaczenie szersze, bo wskazuje na to, że jesteśmy - jak rzecze Paweł - génos tou Theoú - rodem Boga $(\mathrm{Dz}$ 17, 29), co oznacza, że między nami a Nim jest punkt styczności. Przepaść między człowiekiem a Stwórcą nie jest nie do przebycia, bo jako stworzeni na Jego obraz, jesteśmy w stanie poznać Go i dostąpić

20 PG 150,1361 C.

21 Jan z Damaszku, De fide orthodoxa II, c. 12; Y. Spiteris, Ostatni Ojcowie Kościoła: Kabasilas i Palamas, s. 212-218; H. Paprocki, Przebóstwienie, w: Encyklopedia katolicka XVI, kol. 608.

22 L. Uspienski, Teologia ikony, s. 125.

23 De charitate III, 25: PG 90, 1024.

24 J. Meyendorff, La teologia bizantina. Sviluppi e temi dottrinali, tłum. C. Impera, Casale Monferrato 1984, s. 169-172.

25 Jan z Damaszku, De fide orthodoxa, s. 94. 
łączności z Nim. Jeśli zaś właściwie wykorzystamy tę zdolność, to staniemy się „podobni” do Niego, czyli - jak ujął to Jan z Damaszku - upodobnimy się do Niego poprzez pielęgnowanie cnót.

Bez względu na to jak bardzo człowiek jest grzeszny, nigdy nie traci obrazu, natomiast podobieństwo uzależnione jest od jego wyboru, od jego „cnoty”, a przez to podlega ono zniszczeniu przez grzech $^{26}$. Ludzie przy samym stworzeniu byli doskonali nie w stanie dokonanym, lecz tylko możliwym. Obdarzeni od samego początku obrazem, powołani byli do osiągania podobieństwa swym własnym staraniem, wspomaganym łaską Boga. Adam „był dziecięciem, niemającym jeszcze doskonałej zdolności pojmowania”, pisze św. Ireneusz. „Niezbędne było, aby wzrastał i w ten sposób dochodził do swej doskonałości” ${ }^{27}$. Bóg umieścił Adama na właściwej ścieżce, ale droga do celu, który miał osiągnąć, była długa i wymagająca. Dojście więc do niego nie było ani konieczne ani samorzutne. - Ten obraz Adama przed upadkiem nieco różni się od tego, jaki przedstawił św. Augustyn, a który powszechnie przyjęto później na Zachodzie. Zdaniem Augustyna, ludzie w Raju zostali obdarzeni wszelką możliwą wiedzą i prawością: ich udziałem była doskonałość już urzeczywistniona, a nie tylko możliwa do osiągnięcia.

Będąc obrazem Boga, każdy człowiek, nawet najbardziej grzeszny członek rodzaju ludzkiego, jest dla Boga bezgranicznie cenny. „Ujrzałeś brata swego, ujrzałeś Boga swego" ${ }^{28}$, powiedział Klemens z Aleksandrii. To poszanowanie dla każdego człowieka wyraża się w liturgii greckiej, gdy kapłan okadza nie tylko ikony, lecz - obchodząc wnętrze cerkwi - także członków zgromadzenia, czcząc obraz Boży w każdym człowieku obecnym ${ }^{29}$. Znamienne jest również, że składając podczas Eucharystii główne plony ziemi na powrót Bogu, przynosimy je nie w ich postaci pierwotnej, ale przekształcone ręką człowieka, bo oto kapłan składa na ołtarzu nie kłosy pszenicy, lecz upieczony z niej chleb i - nie winogrona, lecz wino ${ }^{30}$.

Stworzenie człowieka na obraz Boga sprawia m.in. to, że ma on wolną wolę. Bóg chciał mieć synów i córki, a nie niewolników. Kościół wschodni odsuwa wszelką naukę o łasce, która zdawałaby się naruszać wolność człowieka. Opisując odniesienie między łaską Boga a wolnością człowieka, Wschód używa pojęcia synergeía (współdziałanie), zgodnie ze słowami Pawła: „Jesteśmy synergoí

$26 \quad$ H. Gross, Gottebenbildligkeit, kol. 1087.

27 Ireneusz Lioński, Dowód prawdziwości nauki apostolskiej, 12.

28 Kobierce, zapisków filozoficznych dotyczacych prawdziwej wiary, tłum. J. Niemirska-Pliszczyńska, Warszawa 1994, s. 69.

29 P. Evdokimov, Prawosławie, s. 280: „Z pewnością najlepszą ikoną Boga jest człowiek”.

$30 \quad$ K. Ware, Prawostawna droga, s. 57-58; J. Meyendorff, La teologia bizantina, s. 172-175. 
- współpracownikami Boga" (1 Kor 3, 9). Chcąc osiągnąć pełną wspólnotę z Bogiem, nie możemy jej wprawdzie dostąpić bez Jego pomocy, lecz musimy wypełnić swoje zadanie. Zarówno Bóg, jak i człowiek wnosi swój wkład we wspólne dzieło, choć to, co czyni Bóg, ma bez porównania większe znaczenie niż ludzkie starania. „Wszczepienie ludzi w Chrystusa i nasze zjednoczenie z Bogiem wymagają współpracy dwóch nierównych, ale równie niezbędnych sił: Bożej łaski oraz woli ludzkiej”31. Doskonałym przykładem tego współdziałania jest Panna Maryja ${ }^{32}$.

Niektórzy chrześcijanie zachodni, zwłaszcza kalwini, odnosili się z podejrzliwością do tej myśli greckiej. Czy nie przypisuje ona zbyt wiele woli człowiekowi, a zbyt mało Bogu? W istocie jednak ta nauka jest uzasadniona, bo Jezus rzecze: „Oto stoję u drzwi i kołaczę: jeśli ktoś usłyszy mój głos i drzwi otworzy, to wejdę do niego..." (Ap 3, 20). Bóg do drzwi puka, lecz ich nie wyłamuje: czeka, aż sami je otworzymy. Jego łaska zaprasza wszystkich, lecz nikogo nie zmusza. Według Jana Chryzostoma, „Bóg nigdy nikogo nie przyciąga do siebie na siłę czy przemocą. Chce, aby wszyscy dostąpili Zbawienia, lecz nikogo nie zmusza”33. Wcześniej zaś Cyryl Jerozolimski rzekł, iż „Boga sprawą jest udzielać łaski, a powinnością twoją jest ją przyjąć i zachować”34.

Jak w wieku $\mathrm{V}$ monofizyci dla swoich celów naciągnęli kilka wypowiedzi Cyryla Aleksandryjskiego - a głównie jego formułę mía phýsis tou Theoú Lógou sesarkôménê (jedna natura Syna Bożego, która wcieliła się) ${ }^{35}$ - tak w wieku XVI protestanci, a zwłaszcza kalwini skrajnie zabarwili kilka zdań ze wczesnych pism Augustyna przeciw Pelagiuszowi, dochodząc - oczywiście wbrew Augustynowi - nawet do przeznaczenia na potępienie, już nie mówiąc o całkowitym zepsuciu natury ludzkiej, które według nich spowodował grzech pierworodny.

Jeśli pelagianie m.in. twierdzili, że nie istnieje grzech pierworodny, a zbawcze dzieło Chrystusa jest tylko przykładem, a nie źródłem życia nadprzyrodzonego, to nie trzeba się dziwić pierwotnemu żarowi Augustyna, także ze względu na jego zaszłość manichejską. W szerokich jednak i doborowych kręgach teologów, zwłaszcza w Galii (dzisiejszej Francji) południowej, uznano, że nie wszystko, co napisał on w dobrym celu, jest równie uzasadnione. Przewodzili

\footnotetext{
31 A Monk of the Eastern Church, Orthodox Spirituality, Crestwood 1987, s. 23.

$32 \quad$ K. Ware, Kościót prawostawny, s. 285-286.

33 Jan Chryzostom, Homilia na stowa „Szawle, Szawle...”, 6: PG 51, 144.

34 Katechezy przedchrzcielne i mistagogiczne, tłum. W. Kania, Kraków 2000, s. 33.

35 Adversus Nestorii blasphemias II: PG 76, 60d; Apologeticus pro duodecim capitibus adversus orientales episcopos VIII: PG 76, 349b; Epistula 45: PG 77, 232d; Epistula 46, nn. 1-4: PG 77, 240a-245a.
} 
im wybitni i święci teologowie, jak Wincenty z Lerinum ${ }^{36}$, Faustus z Regium (Riez), a zwłaszcza Jan Kasjan, który początek i połowę swego życia mniszego spędził na greckim Wschodzie, a potem - w Konstantynopolu na diakona wyświęcony przez Jana Chryzostoma - przez Rzym dotarł do południowej Galii, gdzie zaszczepił owo życie mnisze w pobliżu Marsylii.

Głównie na jego pismach oparł się Benedykt z Nursji, pisząc swą Regula monachorum, a wcześniej archidiakon rzymski, późniejszy Leon Wielki papież, wobec napięcia wschodniego miedzy Cyrylem a Nestoriuszem, w imieniu papieża Celestyna poprosił Jana jako znawcę spraw greckich o streszczenie ich nauk. Kasjan odpowiedział dziełem De incarnatione Domini, contra Nestorium ( $\mathrm{O}$ Wcieleniu Pańskim, przeciw Nestoriuszowi), które - mimo braku nagłośnienia - w istocie legło u podstaw orzeczeń wielkich Soborów Efeskiego i Chalcedońskiego ${ }^{37}$.

W zachodnim sporze pelagiańskim Kasjan wespół z Faustem i Wincentym stali wprawdzie wyraźnie po stronie Augustyna, choć uważali, że nieco przesadził. Mniej od nich umiarkowanemu biskupowi Cezaremu z Arelate (dziś Arles) wykazali Ojcowie z Lerinum na synodzie w Valentia (Valence) stanowisko zbyt ostre, skąd Cezary zwrócił się do papieża z prośbą o wykład w tej sprawie. Otrzymał odpowiedź w 25 punktach, które były po jego myśli. Dodawszy wstęp, a na końcu - wyznanie wiary ${ }^{38}$, sam je ogłosił na zjeździe biskupów w pobliskiej Arausio (Orange) z okazji poświęcenia bazyliki 3 lipca 529 roku. Obrad tam nie było, lecz później utarła się nazwa Concilium Arausicanum ${ }^{39}$.

Był to wprawdzie tylko spór południowo-galijski, lecz ze względu na zatwierdzenie całości tekstu przez kolejnego papieża Bonifacego II, na Kościele łacińskim wywarł on wrażenie, którego skutkiem jest również to, że do dzisiaj Kasjana i jego towarzyszy urzędowo nie czci się jako świętych, natomiast u Greków od początku Jana nie tylko uznano za świętego - w języku cerkiewno-słowiańskim zwą go Priepodóbnyj Kassián Rimliánin, lecz nawet uznano go tam za najwybitniejszego wykładowcę antropologii wschodniej spod znaku synergía - współdziałania człowieka z łaską Pana Boga.

36 Prosper $\mathrm{z}$ Akwitanii, Pro Augustino responsiones ad capitula obiectionum Vincentianarum: PL 51, 177-186.

37 Jakże piękne i wzruszające są słowa przedmowy skierowane do młodego Leona: „[...] vicisti propositum ac sententiam meam [co do milczenia] laudabili studio et imperiosissimo affectu tuo, mi Leo venerande, ac suscipienda caritas mea ac divini ministerii decus, producens me ex ilo praemeditati recessu in publicum formidandumque iudicium...": PL 50, 9-11.

38 Conclusio a Caesario episcopo Arelatensi redacta: DS 396-397.

39 DS 371-395; Breviarium fidei. Wybór doktrynalnych wypowiedzi Kościoła, S. Głowa, I. Bieda (red.), Poznań 1981, s. 198, 296-298. 
Prawosławni uważają, że nauka tego synodu odróżniła chrześcijański Zachód od nauki przyjętej na Wschodzie ${ }^{40}$. Ów początkowy jednak żar Augustyna był prawie niczym w porównaniu z tym, że niemal wszyscy Ojcowie z Bizancjum północnego przez wiele dziesięcioleci byli półarianami co najmniej pod hasłem homoi-oúsios (podobny co do istoty), czyli po linii Boskiej jedności raczej jakościowej niż ilościowej ${ }^{41}$, która jednak jest treścią dogmatu, a została w Nicei podkreślona słowem homo-oúsios tô Patrí (wspólistotny Ojcu) ${ }^{42}$. Nieco zmieniło się to około synodu biskupów wschodnich w Konstantynopolu (381), który

40 Аравсионские соборы wikipedia.org. - W wieku XVII dla Kasjana i towarzyszy na Zachodzie wymyślono uszczypliwy orzecznik „półpelagianie”, podczas gdy Kasjan z Pelagiuszem nie tylko nie miał nic wspólnego, lecz od początku mu się sprzeciwiał, i to rozsądniej niż wielu innych.

41 Bazyli, Epistula VIII. Ad Caesarienses, c. 2: „Tym, co nam zarzucają, że mówimy o trzech Bogach, należy powiedzieć: Wyznajemy jednego Boga nie według liczby, lecz według natury [takiej samej u Trzech] (oú tô arithmố, allá tê phýsei): PG 32, 248; Epistula 236. Ad Amphilochium, c. 6: „Różnica między istotą a hipostazą jest taka sama, jak między czymś ogólnym a jednostkowym, [np.] jak między pojęciem 'istota żyjąca (to zôn)' [lub nawet 'zwierzę' pojęte ogólnie] a tym oto człowiekiem (ton deína ánthrôpon) [pojętym jednostkowo]. Dlatego to wyznajemy, że w Bóstwie jedna jest wprawdzie [ogólnie pojęta] istota (ousían men mían), lecz osobna i pojedyncza (idiásousan) jest [każda] hipostaza, tak że mamy nierozmyte i jasne (asygchýtos... kai tetranôménê) poznanie Ojca i Syna, i Ducha Świętego": ibidem, kol. 884. Jasno tu widać, że dla Bazylego Boska istota wprawdzie jest udziałem trzech hipostaz, lecz sama w sobie jest czymś 'rozmytym' i 'niejasnym' jako coś wyodrębnialnego tylko rozumem. Latynów zaś, wyznających nicejski dogmat o jedności ilościowej, pomawia on - śladem obydwu Euzebiuszów, przyjaciół Ariusza, i swojego mistrza Melecjusza - o rzekomy sabelianizm, choć już w roku 220 papież Kalikst jako pierwszy biskup wyklął Sabeliusza-pochodzącego zresztą ze Wschodu greckiego-a papież Damazy pod koniec wieku IV na wyrost potwierdził to (DS 144-145), i nawet później dodał: „Anathematizamus etiam eos, qui Sabelii sequuntur errorem, eundem dicentes [esse] Patrem, quem Filium”, w: Tomus Damasi: DS 154; W. de Vries SI, Die Obsorge des hl. Basilius um die Einheit der Kirche im Streit mit Papst Damasus, „Orientalia Christiana Periodica“ 40 (1974), s. 55-86.

42 R. Barr, Breve patrologia, tłum. C. Orecchia, C. Gianotto, s. 91-96. - Ich przywódca po Melecjuszu, Bazyli z Cezarei, pochodził ze stronnictwa Bazylego, biskupa miasta Ágkyra (Ankara) i Jerzego, biskupa Laodikei - obydwu przeto z Azji Mniejszej, gdzie leżała Kapadocja, którzy ok. połowy IV wieku chcieli odciąć się od pełnego arianizmu Aecjusza, biskupa Antiochii, oraz jego ucznia Eunomiusza, późniejszego biskupa Kýzikos nad morzem Marmara; J. McSorley, St Basil the Great w: The Catholic Encyclopedia II, Nowy York 1907 (newadvent.org; wikisource.org): „With regard to the question of his association with the Semi-Arians, Philostorgius speaks of him [o Bazylim] as championing the Semi-Arian cause, and Newman says he seems unavoidably to have Arianized the first thirty years of his life. The explanation of this, as well as of the disagreement with the Holy See, must be sought in a careful study of the times, with due reference to the unsettled and changeable condition of theological distinctions, the lack of anything like a final pronouncement by the Church's defining power, the «lingering imperfections of the Saints» (Newman)". 
po latach siedemdziesięciu uznano za sobór powszechny ${ }^{43}$. Otóż pod wpływem cesarza Teodozjusza, Latyna z Hiszpanii, przeto wiernego Nicei, oświadczyli oni, że przyjmują wprawdzie homo-oúsios Soboru w Nicei, ale w znaczeniu, że trzy hypostáseis - Boskie byty jednostkowe są podobne co do istoty ${ }^{44}$. Stąd nazywani są nowymi nicejczykami. Także dzisiaj prawosławni na ogół uważają, że są trzy byty Boskie, a Bóg jest jeden głównie dlatego, że jeden jest Ojciec, od którego pochodzi Syn i Duch Święty ${ }^{45}$. Niektórzy dodają tu perchốrêsin, czyli wspólprzenikanie się trzech hipostaz.

Należało to wyszczególnić, bo św. Augustyn według focjan, czyli prawosławnych, wprowadził teologię łacińską na ścieżki niewskazane, głównie w nauce o Trójcy; a przecież on tylko nieco rozwinął to, co już w wieku II - także na podstawie pism greckich - przedłożył geniusz Tertuliana. Zazwyczaj mówią o nim bez wielkiego szacunku, podczas gdy niemal wyroczniami są dla nich teologowie ledwo przysposobieni - począwszy od Focjusza do Filareta Drozdowa w wieku XIX - których mimo zastrzeżeń i przeciwwskazań uznają za świętych. Nie dowiedzieli się, że na wielki Sobór w Efezie, który czci i sławi

43 I. Ortíz de Urbina, El Espíritu Santo en la teología del siglo IV desde Nicea a Constantinópla, „Estudios Trinitarios” 17 (1983), s. 36: „Jeżeli zaś od Soboru Chalcedońskiego (451) wszedł on [synod konstantynopolski] w poczet soborów powszechnych (ecuménicos), to stało się to drogą pewnej fictio iuris, bo w Chalcedonie zostało ogłoszone i prawnie uznane Credo, które byli przyjęli biskupi zebrani w Konstantynopolu”; B. J. Huculak, W sprawie odniesienia poglądu Focjusza do Symbolu Nicejsko-Konstantynopolitańskiego, s. 150-152.

44 F. Dünzl, Breve storia del dogma trinitario nella Chiesa antica, tłum. C. Danna, Brescia 2007, s. 139-140: ,[...] il vescovo Melezio di Antiochia era tornato nella sua città episcopale e già nel 379 aveva radunato attorno a sé un grande sinodo composto da più di centocinquanta vescovi neoniceni. Tale sinodo aveva approvato una compilazione di documenti romani... Si tratta di quelle lettere redatte e inviate negli anni precedenti dal papa Damaso...”; C. Moreschini, I Padri Cappadoci. Storia, letteratura, teologia, Rzym 2008, s. 241-242: „Egli [Atanazy] cercava un compromesso con gli omeusiani [homoioúsios] ed eventualmente con gli omei [hómoios], escludendo solamente gli anomei [an- ${ }^{h}$ ómoios]. Di conseguenza nel 363 ad Antiochia vari vescovi di quelle tendenze, insieme con Melezio d'Antiochia, accettarono in un concilio il «consustanziale [homo-oúsios]), ma in senso omeusiano [homoi-oúsios]"; B. J. Huculak, Jana Dunsa Szkota nauka o osobie w Trójcy, „Roczniki Teologii Dogmatycznej” 3 (2011), s. 114-119.

45 Grzegorz z Nazjanzu, Oratio XXIX - theologica III. De Filio I, n. 2: „My natomiast czcimy ‘monarchię> [...] jedną poprzez równą godność natury [trzech Podmiotów] (phýseôs homotimía), zgodność woli, tożsamość ruchu i nawrót do Jednego [Ojca] Tych, którzy są z Niego (pros to hen tôn ex autoú sýnneusis)"; Jan z Damaszku, De fide orthodoxa, c. 8: „Dlatego to o Ojcu, Synu i Duchu Świętym mówimy nie jako o trzech Bogach, lecz raczej jako o jednym Bogu, Świętej Trójcy, bo Syn i Duch zwracają się ku jednej Przyczynie [Ojcu], a nie składają się i nie zlewają się, jak zlewał [je] Sabeliusz"; B. J. Huculak, Podstawy greckiej teologii Trójcy, Kalwaria Zebrzydowska 2005, s. 154-158; Boska osoba wedlug Jana ze Szkocji, „Przegląd Kalwaryjski” 15 (2011), s. 102-104; B. Bobrinskoy, Le mystère de la Trinité. Cours de théologie orthodoxe, Paryż 1986, s. 268-272. 
papieża Celestyna, ten wysłał przedstawicieli czterech, a wśród nich właśnie Augustyna. On tam nie dotarł, bo nieco wcześniej umarł, lecz ów Sobór przychylając się do stanowiska Zachodu - potępił także pelagianizm; a to było owocem prac Augustyna ${ }^{46}$.

Podobnie jak prawosławnym obce jest pojęcie odpustu, tak na ogół nie uważają, że poprzez przyjęcie i zachowanie łaski Bożej, człowiek gromadzi zasługi. Przeważa u nich myśl, że łaski Boga są zawsze wolnymi darami Jego miłości do ludzi, a ci wobec Niego nie mogą mieć jakichkolwiek roszczeńn ${ }^{47}$. My - katolicy wprawdzie też nie postrzegamy zasługi po linii roszczenia, lecz jako prawdę wiary wyznajemy istnienie zasług i leżącego u ich podstaw wzrostu w łasce dzięki dobrym czynom ${ }^{48}$.

Wydaje się jednak, że ta rozbieżność jest bardziej słowna niż rzeczowa, jeśli prawosławni - także przez dojmujące posty - bardzo poważnie biorą zalecenie Pawła, by nad własnym zbawieniem pracować „z bojaźnią i drżeniem” (Flp 2, 12), bo „wiara, jeśli nie byłaby połączona z uczynkami, to martwa jest sama w sobie" (Jk 2,17). Świadczy zaś o tym również to, że sprawy antropologii nigdy nie były przedmiotem uzgodnień dogmatycznych przy odnawianiu jedności kościelnej, zwłaszcza na Soborach w Lyonie (1274) i we Florencji (1438) ${ }^{49}$.

Człowiek został stworzony nie tylko na obraz Boga jedynego według istoty, lecz także troistego według Osób. Stąd wynika, że podobnie jak Bóg, spełnia się on poprzez życie wspólne. Jak trzy Boskie Osoby żyją jedna w drugiej i dla siebie nawzajem, tak i człowiek - stworzony na obraz Trójcy - staje się w pełni osobą, gdy spogląda na świat także oczyma innych oraz przyjmuje radości i smutki innych jako swoje własne. „Stałem się wszystkim dla wszystkich wyznaje Paweł - aby zbawić co najmniej niektórych" (1 Kor 9, 22), dlatego zachęca: „Cieszcie się z tymi, którzy się cieszą, płaczcie z tymi, którzy płaczą. Bądźcie zgodni we wzajemnych uczuciach" $(\mathrm{Rz} 12,15)$. Każda istota ludzka jest wprawdzie niepowtarzalna, lecz każdy w tej wyjątkowości został stworzony do wspólnoty z innymi. „Jeden drugiego brzemiona noście, a tak wypełnicie prawo Chrystusa” (Ga 6, 2). „Chwałę [Boską], którą mi dałeś [Ojcze] - mówi Pan - dałem im, aby stanowili jedno, jak My jedno [stanowimy]: Ja w nich, a Ty we Mnie" (J 17, 22).

$46 \quad$ Rzecz pod imieniem Celestiusza-ucznia Pelagiusza, który do stanu skrajnego doprowadził naukę mistrza - potępił Sobór ekumeniczny Efeski, Actio VII, cann. 1. 4: DS 267-268.

47 Zdają się tu na swój sposób rozumieć Pawła, który do Efezjan pisze: „Łaską jesteście zbawieni [...]. Łaską jesteście zbawieni przez wiarę; a to pochodzi nie od was, lecz jest darem Boga: nie z uczynków, aby się nikt nie chlubił" (2, 5. 8-9).

48 Sobór ekumeniczny Trydencki, Sessio VI, can 32: DS 1582.

49 E. Przekop, Rzym - Konstantynopol. Na drogach podziału i pojednania, Olsztyn 1987, s. $59-80$. 
Wierzyć, że człowiek został uczyniony na obraz Boga, znaczy wierzyć, że został on stworzony do łączności z Bogiem, a jeśli on odrzuca tę jedność, to przestaje być w pełni człowiekiem. Nie ma czegoś takiego jak "człowiek naturalny” istniejący samodzielnie, bez odniesienia do Boga, nawet jeśli usiłuje to sobie wmówić, wykrzywiając swą tożsamość: „Mówi głupi w swoim sercu: «Nie ma Boga»" (Ps 53, 2). Prawda o obrazie oznacza więc, że Bóg stanowi najbardziej wewnętrzne sedno istnienia człowieka. Boskość jest pierwiastkiem rozstrzygającym w naszym człowieczeństwie; a kto odrzuca wzgląd na to, co Boskie, ten traci również poczucie tego, co prawdziwie ludzkie ${ }^{50}$. Na ów nadprzyrodzony pierwiastek w obrazie - obok głównego skojarzenia sakramentalnego - wskazują także określenia Pawła, jak „zadatek Ducha”, „pierwociny Ducha”, „pieczęć Ducha [Świętego]" (Rz 8, 23; 2 Kor 1, 22; 5, 5; Ef 1, 13-14; 4, 30).

\section{Grzech pierworodny i jego skutki}

Bóg dał Adamowi wolną wolę, czyli moc wyboru między dobrem a złem, i dlatego to do Adama należało rozstrzygnięcie, czy przyjąć postawione przed nim zadanie, czy też nie. On je odrzucił. Zamiast podążać drogą wytyczoną przez Boga, on nie posłuchał i zboczył. Upadek Adama polegał głównie na jego nieposłuszeństwie wobec woli Boga: przeciwstawił jej swoją własną wolę, a przez to odsunął się od Niego. Następstwem było pojawienie się choroby i śmierci. Odwracając się od Boga, który jest nieśmiertelnością i życiem, ludzie doprowadzili się do stanu sprzecznego $z$ naturą, a ten doprowadził do rozpadu ich bytu i w końcu do śmierci. Ponadto Adam i jego potomkowie przeszli pod panowanie grzechu i zła. Każdy noworodek przychodzi na świat, w którym panuje grzech i łatwo jest popełniać zło, a trudno czynić dobro. Ludzka wola jest nadwątlona i osłabiona pożądliwością. Tym duchowym następstwom grzechu pierworodnego podlegają wszyscy.

Pozostając przy nieco mniej podniosłym pojęciu stanu człowieka przed upadkiem, prawosławie jest także mniej niż Zachód surowe w postrzeganiu następstw ${ }^{51}$. Otóż Adam upadł nie z wielkich wyżyn wiedzy i doskonałości, lecz ze stanu nierozwiniętej prostoty i stąd za swój błąd nie powinien być osądzany zbyt ostro. Prawosławni nie utrzymują, że jego upadek całkowicie pozbawił go łaski Bożej. W przeciwieństwie do kalwinów, a zgodnie z nami - katolikami nie twierdzą, jakoby wskutek upadku ludzie ulegli całkowitemu zepsuciu i stali się niezdolni do pragnień dobrych. Poza tym uważają, że obraz Boży jest wprawdzie przez grzech zniekształcony, lecz nigdy nie zostaje zniszczony. Podczas greckiej

$50 \quad$ J. Meyendorff, La teologia bizantina, s. 171-172.

51 J. Meyendorff, La teologia bizantina, s. 176-178. 
liturgii są wypowiadane słowa: „Obrazem jestem Twej chwały niewypowiedzianej, nawet jeśli rany grzechu noszę”.

Skoro zachowujemy obraz Boży, to zachowujemy też wolną wolę, choć grzech ogranicza jej zakres działania. Nawet po upadku Bóg „nie odbiera ludziom siły woli, która jest wolą okazywania [Mu] albo nieokazywania $\mathrm{Mu}$ posłuszeństwa" ${ }^{52}$. Te słowa napisał Dosyteusz, grecko-prawosławny patriarcha Jerozolimy, który na synodzie w roku 1672 przeciw półkalwińskiemu wyznaniu wiary Cyryla Lukarisa, patriarchy Konstantynopola, ogłosił własne wyznanie wiary; a później uznano je za wykład urzędowy Kościoła prawosławnego. Większość Greków uważa, iż ludzie samoczynnie dziedziczą zepsucie i śmiertelność Adama, lecz nie jego winę; a stają się winni jedynie wówczas, gdy ze swojego wyboru naśladują go. Prawosławny obraz upadłego człowieka jest mniej przygnębiający niż ten, który stworzyli protestanci, a zwłaszcza Kalwin, przez co bliższy jest nauce katolickiej.

Człowiek po grzechu przestał uważać stworzenie za dar Boga, który należy Mu na powrót składać z dziękczynieniem, a zaczął je postrzegać jako swoją własność, którą należy posiąść i wyzyskać. Już nie widział osób i rzeczy takimi, jakimi one są same w sobie i w Bogu, a postrzegal je po linii zaspokojenia przyjemności własnej. Świat dla niego przestał być jakby przejrzystym oknem, przez które spoglądać miał na Boga (Rz 1, 19-20), a stał się matowy.

Upadek człowieka przyniósł skutki zarówno fizyczne, jak i duchowe. Wbrew pierwotnemu zamysłowi Boga, ludzie zostali objęci bólem, chorobami i zanikiem ciała. Radość kobiety z wydawania na świat nowego człowieka została zmieszana z bólem rodzenia $(\mathrm{Rdz} 3,16)$. Ludzie zaczęli też podlegać oddzieleniu duszy od ciała przy śmierci. Tę jednak można rozumieć niekoniecznie jako karę, lecz jako sposób wyzwolenia, dany przez kochającego Boga. On w miłosierdziu swym nie chciał, by ludzie żyli nieskończenie długo na tym upadłym świecie, pochwyceni na zawsze w błędne koło swych myśli, i dlatego zapewnił im sposób ucieczki. Śmierć bowiem nie jest końcem życia, lecz początkiem jego odnowy.

Spoglądamy poza śmierć fizyczną ku ponownemu zjednoczeniu duszy z ciałem podczas powszechnego Zmartwychwstania w Dniu Ostatnim. Oddzielając duszę od ciała przy śmierci, Bóg postępuje jak garncarz, który na widok dzbana zniekształconego na kole, zgniata go, by z gliny ponownie wytoczyć dzban kształtny (Jr 18, 1-6). Podkreśla to wypowiedź greckiej liturgii pogrzebu:

Niegdyśs stworzyłeś mię z niczego, / i zaszczyciłeś mię Twoim Boskim obrazem; / ale gdy nie posłuchałem przykazania, / na powrót wróciłeś mię do ziemi, z której zostałem wzięty. // Poprowadź mię z powrotem ku Twemu podobieństwu, / przywracając mi moje dawne piękno.

$52 \quad$ Dosyteusz, Wyznanie wiary III. XIV. 
W wymiarze zaś duchowym upadek zepchnął ludzi w rozczarowanie, znudzenie i duchową zapaść. Praca, która miała radować, stała się ciężarem. „Jestem świadom - pisze Paweł - że we mnie, to jest w moim ciele (en tê sarkí mou), nie mieszka dobro, bo łatwo przychodzi mi chcieć tego, co dobre, lecz wykonać - nie". (Rz 7, 18). Walkę ascetyczną prowadzimy przeciw ciału jako materii (sarx), a nie ciału jako składnikowi człowieka (sốma). Wymaga się jej od wszystkich chrześcijan, a nie tylko od mnichów. Powołanie mnisze i powołanie małżeńskie są równoległe i wzajem się uzupełniające. Mnich czy mniszka nie mniej niż żonaty chrześcijanin, dąży do objawienia wewnętrznego dobra materialnego stworzenia i ciała ludzkiego. Różnica polega tylko na warunkach, w jakich prowadzona jest walka ascetyczna. Obaj odrzucają grzech, a szanują świat jako dzieło Boga.

\section{***}

Antropologia grecka wykazuje kilka znamion wyrazistych. Otóż jak zasadniczo cała teologia wschodnia, jest ona określana jako apofatyczna, gdyż porusza się głównie drogą apóphasis - zaprzeczenia, co polega na mniejszej trudności w oświadczeniu, czym nie jest Bóg, a także jego stworzenie z człowiekiem na czele, aniżeli w twierdzeniu, kim On jest ${ }^{53}$. Wskazuje więc ona na niedostępną głębię człowieka i na jego zasadniczą otwartość wobec Pana Boga. Stąd wynika pewien brak uściśleń teologicznych, który jednak dotyczy głównie nauki o sprawach ostatecznych ${ }^{54}$. Poza tym, jest ona teologią obrazu, który najczęściej jest odróżniany od podobieństwa. Ono jest dokonaniem, spełnieniem obrazu, pojmowanego jako zadanie osiągnięcia łaski przebóstwienia.

Po upadku grzechowym obraz został nienaruszony, lecz podobieństwo uległo zniszczeniu, a przywraca je zbawcze dzieło Chrystusa, którego natura ludzka jest praobrazem, czyli wzorcowym obrazem Boga. Ten bowiem ,zajaśniał w sercach naszych, aby oświetlić je poznaniem chwały Bożej [będącej] na obliczu Jezusa Chrystusa" (2 Kor 4, 6). Człowiek nie tylko walczy z grzechem i dąży do Zbawienia, lecz także jest istotą twórczą, a nawet „wspólpracownikiem Boga” (1 Kor 3, 9) na wzór Boskiego Twórcy, który zresztą już w Raju polecił, by ludzie „napełnili ziemię i uczynili ją sobie poddaną" (Rdz 1, 28).

53 Pseudo-Dionizy Areopagita, Pisma teologiczne, tłum. M. Dzielska, Kraków 2005, s. $325-$ 330; M. Gogacz, Apofatyka jako opis doświadczenia mistycznego, w: Św. Bonawentura. Życie i myśl, S. C. Napiórkowski, E. I. Zieliński (red.), Niepokalanów 1976, s. 366-392.

54 A. Sarwa, Rzeczy ostateczne człowiekaiświata. Eschatologia Kościoła wschodniego, Łódź2003; A. Turincew, Przybliżenie eschatologii prawosławnej, w: Katechizm Kościoła prawosławnego, tłum. A. Kuryś, M. Romanek, H. Paprocki, J. Rozkrut, Kraków 2001, s. 455-460. 
Nauka wschodnia, zwracając uwagę bardziej na zestrój bytowy człowieka niż na działanie jego rozumu i woli, jest antropologią przebóstwienia, ku któremu przeznacza go obraz Boży, zadając mu je. Łaska więc jest nieodłączna od natury ludzkiej, bo ta - jako stworzona na obraz Boży - jest teoforyczna, gdyż od początku nosi pierwiastek Boski przeznaczony do wzrostu, rozkwitu oraz uwieńczenia wskutek Zmartwychwstania w Chrystusie ${ }^{55}$. Nauka ta więc jest antropologią wielkanocną, bo jej podstawą jest przeobfite uwielbienie, czyli przebóstwienie człowieczeństwa Jezusa dzięki Jego zwycięstwu nad śmiercią.

Z tego wykładu, którego ostatnimi przedstawicielami wśród Ojców byli Maksym Wyznawca i Jan z Damaszku, daleko idące wnioski wyciągnął w wieku XIV Grzegorz Palamas, skupiając uwagę na Przemienieniu Pańskim, które na Górze Tabor miało być przebłyskiem chwały Zmartwychwstania. Stwierdził on, że natura ludzka, także w składniku cielesnym, może być przemieniona światłem Taboru, promieniującym z chwalebnego człowieczeństwa Chrystusa. Tak oto Bogoczłowieczeństwo natury ludzkiej (to theandrikón), polegające na złączeniu, lecz niezmieszaniu obydwu składników, a zasiane w niej przy stworzeniu na obraz Boży, wydaje owoc dojrzały w człowieku przebóstwionym, który przez to osiągnął podobieństwo Boże.

Antropologia w ostatnich dziesięcioleciach coraz bardziej skupia uwagę teologów wschodnich, a myśl rosyjska - choć podobnie jak grecka jest przeniknięta prawdą o Trójcy i Wcieleniu - została uznana wręcz za antropocentryczną ${ }^{56}$. Wydaje się więc, że wymiana myśli w tej dziedzinie między teologami Zachodu i Wschodu jest dla obu stron cenna, ubogacająca, i warta podejmowania starań podobnych do tego, co czyni się w głównych przedmiotach dialogu katolicko-prawosławnego.

Słowa klucze: przebóstwienie, duch-dusza-ciało, obraz Boga, podobieństwo do Boga, grzech pierworodny.

\section{Bibliografia:}

1. A Monk of the Eastern Church, Orthodox Spirituality, Crestwood 1987.

2. Bazyli, Epistula 8. Ad Caesarienses.

3. Bazyli, Epistula 236. Ad Amphilochium.

4. Bazyli, Epistula VIII. Ad Caesarienses.

5. Bazyli, O Duchu Świętym, Sources Chrétiennes 17 (PG 32).

55 H. Paprocki, Teoforyczna natura, w: Encyklopedia katolicka XIX, kol. 651.

56 W. W. Zienkowskij, Istorija russkoj fitosofii I, Paryż 1948, s. 19-20; ibidem II, Paryż 1950, s. 469: 'Antropołogia' (Skorowidz). 
6. Barr R., Breve patrologia, thum. C. Orecchia, C. Gianotto.

7. Benedykt XVI, Katecheza Sant'Ireneo di Lione (28 III 2007).

8. Bobrinskoy B., Le mystère de la Trinité. Cours de théologie orthodoxe, Paryż 1986.

9. Breviarium fidei. Wybór doktrynalnych wypowiedzi Kościoła, S. Głowa, I. Bieda (red.), Poznań 1981.

10. Bux N., Loconsole M., I Misteri degli orientali. I sacramenti bizantini comparati con la liturgia romana e i riti giudaici, Siena 2006.

11. Cezary z Arles, Conclusio a Caesario episcopo Arelatensi redacta: DS 396-397.

12. Cyryl Aleksandryjski, Adversus Nestorii blasphemias: PG 76.

13. Cyryl Aleksandryjski, Apologeticus pro duodecim capitibus adversus orientales episcopos: PG 76.

14. Cyryl Aleksandryjski, Epistula 45: PG 77.

15. Cyryl Aleksandryjski, Epistula 46: PG 77.

16. Cyryl Jerozolimski, Katechezy przedchrzcielne i mistagogiczne, tłum. W. Kania, Kraków 2000.

17. Dosyteusz, Wyznanie wiary.

18. Dünzl F., Breve storia del dogma trinitario nella Chiesa antica, tłum. C. Danna, Brescia 2007.

19. Evdokimov P., Prawostawie, tłum. J. Klinger, Warszawa 1964.

20. Gogacz M., Apofatyka jako opis doświadczenia mistycznego, w: Św. Bonawentura. Zycie i myśl, S. C. Napiórkowski, E. I. Zieliński (red.), Niepokalanów 1976.

21. Gross H., Gottebenbildligkeit, w: Lexikon für Theologie und Kirche IV (1960).

22. Grzegorz z Nazjanzu, Oratio XXIX - theologica III. De Filio.

23. Huculak B. J., Boska osoba wedtug Jana ze Szkocji, „Przegląd Kalwaryjski” 15 (2011).

24. Huculak B. J., Jana Dunsa Szkota nauka o osobie w Trójcy, „Roczniki Teologii Dogmatycznej" 3 (2011).

25. Huculak B. J., Najświętsza Trójca na tle dzieła zbawczego, Kalwaria Zebrzydowska 2000.

26. Huculak B. J., Podstawy greckiej teologii Trójcy, Kalwaria Zebrzydowska 2005.

27. Huculak B. J., W sprawie odniesienia pogladu Focjusza do Symbolu Nicejsko-Konstantynopolitańskiego, „Analecta Cracoviensia” 25 (1993).

28. Ireneusz Lioński, Adversus haereses.

29. Ireneusz Lioński, Dowód prawdziwości nauki apostolskiej, 12.

30. Jan Chryzostom, Homilia na stowa „Szawle, Szawle...”: PG 51.

31. Jan Duns Szkot, Reportata Parisiensia III, d. 7, q. 4: Opera omnia, t. XXIII, Paryż 1894.

32. Jan Paweł II, Katecheza Duch, który od Ojca i Syna pochodzi (7 XI 1990), w: Jan Paweł II, Wierzę w Ducha Świętego, Pana i Ożywiciela, Warszawa 1992.

33. Jan z Damaszku, De fide orthodoxa.

34. Jan z Damaszku, Mowa VI na Narodzenie Najświętszej Maryi Panny.

35. Katechizm Kościoła Katolickiego.

36. Klemens z Aleksandrii, Kobierce, zapisków filozoficznych dotyczacych prawdziwej wiary, tłum. J. Niemirska-Pliszczyńska, Warszawa 1994. 
37. Klinger J., Kilka problemów związanych z nauką o Trójcy Świętej w prawosławnej teologii XX wieku, w: J. Klinger, O istocie prawostawia. Wybór pism (wyd. M. Klinger, H. Paprocki), Warszawa 1983.

38. Maksym, De charitate: PG 90, 1024.

39. McSorley J., St Basil the Great w: The Catholic Encyclopedia II, Nowy York 1907 (newadvent.org; wikisource.org).

40. Meyendorff J., La teologia bizantina. Sviluppi e temi dottrinali, tłum. C. Impera, Casale Monferrato 1984.

41. Miguéns M., Base escriturística de la doctrina de Escoto sobre el primado de Cristo, w: De doctrina Ioannis Duns Scoti. Acta Congressus Scotistici Internationalis Oxonii et Edinburgi 11-17 IX 1966 celebrati, III: Problemata theologica, Rzym 1968.

42. Moreschini C., I Padri Cappadoci. Storia, letteratura, teologia, Rzym 2008.

43. Ortíz de Urbina I., El Espíritu Santo en la teología del siglo IV desde Nicea a Constantinópla, „Estudios Trinitarios” 17 (1983).

44. Orygenes, Komentarz do Ewangelii Jana II, Sources Chrétiennes 120.

45. Paprocki H., Przebóstwienie, w: Encyklopedia katolicka XVI.

46. Paprocki H., Teoforyczna natura, w: Encyklopedia katolicka XIX.

47. Prosper z Akwitanii, Pro Augustino responsiones ad capitula obiectionum Vincentianarum: PL 51.

48. Przekop E., Rzym - Konstantynopol. Na drogach podziatu i pojednania, Olsztyn 1987.

49. Pseudo-Dionizy Areopagita, Pisma teologiczne, tłum. M. Dzielska, Kraków 2005.

50. Sarwa A., Rzeczy ostateczne człowieka i świata. Eschatologia Kościoła wschodniego, Łódź 2003.

51. Seiller L., Un théologien scotiste - le Révérend Père Déodat de Basly (1862-1937), „La France Franciscaine” 21 (1938).

52. Slipyj J., Die Trinitätslehre des byzantinischen Patriarchen Photios, w: Opera omnia I, Rzym 1968.

53. Špidlik T., Myśl rosyjska. Inna wizja człowieka, tłum. J. Dembska, Warszawa 2000.

54. Spiteris Y., Ostatni Ojcowie Kościoła: Kabasilas i Palamas, tłum. B. Widła, Warszawa 2006.

55. Turincew A., Przybliżenie eschatologii prawosławnej, w: Katechizm Kościoła prawosławnego, tłum. A. Kuryś, M. Romanek, H. Paprocki, J. Rozkrut, Kraków 2001.

56. Tyciak J., Die Liturgie als Quelle östlicher Frömmigkeit, Fryburg Br. 1937.

57. Uspienski L., Teologia ikony, Poznań 1993.

58. Veuthey L. Jan Duns Szkot - myśl teologiczna, tłum. M. Kaczyński, Niepokalanów 1988.

59. Vries W. de, Die Obsorge des hl. Basilius um die Einheit der Kirche im Streit mit Papst Damasus, „Orientalia Christiana Periodica“ 40 (1974).

60. Ware K., Kościót prawosławny, tłum. Wł. Misijuk, Białystok 2002.

61. Ware K., Prawostawna droga, tłum. s. Nikolaia z Bussy-en-Othe, Białystok 1999.

62. Zienkowskij W. W., Istorija russkoj fitosofii I, Paryż 1948.

63. Zienkowskij W. W., Istorija russkoj fitosofii II, Paryż 1950. 